\title{
THE HISTORICAL DEVELOPMENT OF DETERMINERS: A PARAMETRIC APPROACH
}

\author{
Keiko Yamamoto \\ Kwansei Gakuin University
}

\begin{abstract}
Japanese noun phrase allows double determination such as kare-no kono hon while its counterpart in Present-day English is ungrammatical (*his this book). Such differences of noun phrase structure in terms of premodification among languages are attributed to the different projections, NP and $\mathrm{DP}$, in some of the current issues. On the basis of the fact that older English allows double determination, we propose that postulation of the shift of the parameter from [-D] to [+D] explains the similar contrast between older English and PE. The proposed analysis provides a unified explanation for the development of group genitive, affectedness condition, appearance of his genitive, and disappearance of modifiable pro-forms, extraction from NP, all of which have been treated separately in previous literature.*
\end{abstract}

1. Introduction. Present-day English (PE) does not allow double or multiple determiners (e.g. a demonstrative and a possessive) on a single head noun in NP structure, whereas Japanese accepts such cooccurrences. What draws our attention is that Old English (OE), Middle English (ME), and Early Modern English (EModE) also allow this structure, though its behaviour is not necessarily the same as that of Japanese. This contrast is shown in la-d.
(1) a. *that/the his interesting story
b. *their this opinion
c. kare-no sono akai kuruma
he-GEN that red car
'that red car of his'

* This is a revised version of the paper read at The Sixth National Conference of The English Linguistic Society of Japan. I am grateful to Taro Kageyama, whose suggestions and valuable comments led to this article. My thanks are also due to the conference participants and two anonymous EL reviewers, who gave me helpful comments. The responsibility for inadequacies is my own.

English Linguistics 6 (1989) 1-17 - - 1-

(C) 1989 by the English Linguistic Society of Japan 


\section{d. his seo gemæne spræc}

his that public statement

'his public statement' $(\mathrm{GD}(\mathrm{C})$ 150.32-Mitchell 1985)'

This paper is an attempt to explain why this particular structure existed in older English and was lost on the arrival of PE, with the focus of attention on the two types of projections, NP and DP, proposed by Fukui 1986, 1988 and Abney 1987. For empirical justification, we will examine some related historical changes in English and relevant data in other languages as well.

2. Functional CATEGORY. Fukui develops a new system of projection in which lexical categories (e.g. N, V, A) are distinguished from what he calls FUNCTIONAL categories (COMP, INFL, DET). Under the traditional assumptions, both lexical and functional categories are said to participate fully in the X-bar schemata. Fukui 1988, on the other hand, argues that functional categories may project up to the double-bar level and have the specifier which closes off their projections, while lexical categories project up to the single-bar level and the iteration is allowed at that level with no specifiers at all. In this system, English has the functional category D of articles and $-s$ in NP structure, while Japanese does not. Thus, unlike English, Japanese has no articles, its demonstratives do not serve as D as shown in 1c, and it has modifiable pro-forms as in kinoo-no kare 'yesterday's he' (Fukui 1986: 231).

Fukui's system seems to be on the right track, but will need some modification. In his proposal, the Spec position is a non-A position, because the so-called 'external argument' is generated within the projection of a lexical category at D-structure and moves to the Spec to receive Case, as shown in $2 \mathrm{a}$.

(2)

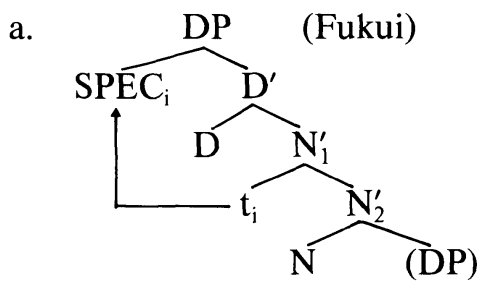

b.

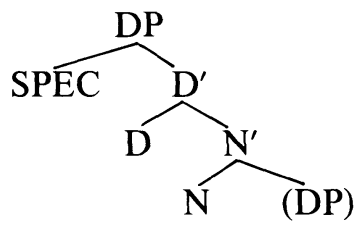

However, we should like to suggest the possibility of having an external

${ }^{1}$ In $\mathrm{GD}(\mathrm{H}) 150.32$ the order is reversed: seo his gemæene spræec (Mitchell). We owe not a few examples to Mitchell 1985, Mustanoja 1960, and so forth. 
argument base-generated in the Spec position when the external $\theta$-role is Possessor ( $m y$ book), as shown in $2 \mathrm{~b}$. In this case, the external $\theta$-role will be assigned by $\mathrm{D}$. On the other hand, Agent $\theta$-role (their destruction of the city) is assigned by $\mathrm{N}_{2}^{\prime}$ and therefore indirectly by $\mathrm{N}$, along the lines of Fukui (1986: 106). What is crucial now is that under the present analysis, the Spec position of $\mathrm{D}$ is an $\mathrm{A}$ position. This assumption will enable us to capture the difference between $\mathrm{OE} / \mathrm{ME}$ and $\mathrm{PE}$ in a more satisfactory way (Section 4).

3. AbSEnCE OF D in OE AND ME. We will now show that OE, ME, and EModE lack the functional category D. In the earlier stage of English, examples of cooccurrence of demonstratives and possessive pronouns or genitives ${ }^{2}$ in prenominal position are amply attested. Here we adduce typical examples.

( 3 ) $[$ Dem] [Poss/Gen] ([Adj]) [N]

a. Hie ba lærde se heora halga bisceop

them then instructed that their holy bishop

'Then their holy bishop instructed them'

(B1Hom 201.24)

b. ðе gehyrað むæt halige Godes word who hear that holy God's word 'who hear the holy word of God'

(ÆHom IV. 294-Allen)

c. Gif du бese godes ziue bizeten miht

If you this God's gift get can

'If you can get this gift of God's' (Vices \& V 63.25)

d. this his distemper he is in now (Wives IV ii 28)

e. There is $a$ friend of mine come to town

(Wives IV v 76)

f. That flattering tongue of yours won me (As IV i 184)

(4) [Adj] [Poss/Gen/Dem] [N]

a. Halige men ponne ongeaton pæt he wæs sop Godes Holy men then knew that he was true God's Sunu

Son

2 In order to avoid terminological confusion, we apply the term 'possessive pronoun' both to a genitive of pronoun and a possessive adjective, which are distinguished in earlier languages, and the term 'genitive' to a genitive of noun. 
'Holy men then knew that he was the true son of God' (BlHom 29.26)

b. and mid rihte godes dome he was ut zedon and by right God's doom he was out put 'and by the right doom of God he was put out'

(Vices \& V 51.20)

c. mid sele pan kinge with good the king 'with the good king'

d. sweet my child

(Love I ii 68)

Demonstratives precede possessive pronouns or genitives in $3 a-d$. In $3 a$, each of $s e$ 'that', heora 'their' and halga 'holy' modifies bisceop 'bishop'. $3 \mathrm{~b}$ shows daet halige 'that holy' premodifying word 'word', not Godes 'God's' because of the agreement. It is evident that Godes also modifies word. Among the ME examples we find 3c, where dese 'this' and godes 'God's' modify ziue 'gift'. Such linkage of elements can also be seen in EModE as in 3d. On the other hand, the of-genitive like $3 \mathrm{e}, \mathrm{f}$ was already prevailing and seems to have replaced the older pattern by the seventeenth century. In 4 , adjectives precede the other elements. Sop 'true' in 4a modifies Sunu 'Son' and in 4b rihte 'right' modifies dome 'doom'. This pattern of 4 , which did not occur so frequently as 3 even in OE, became rare in the late sixteenth century, though examples like $4 \mathrm{~d}$ that are lost in PE were still found.

We assume that the types of 3 and 4 have the base-generated word order, although the type of 3 seems unmarked because of its frequency, and that the relative order of modifiers is determined by semantic and pragmatic factors, just as the order of adjectives in PE is restricted semantically. It should be noted that postnominal genitives are also base-generated. $^{3}$ Thus the data make us believe that at the earliest stage, English demonstratives and genitives/possessive pronouns were not distinct from adjectives, generated at the repeated $\mathrm{N}^{\prime}$ level without closing off the projection. Let us now turn to the next examples. In the type of 5, genitives/possessive pronouns show up at the beginning.

3 Notice that in Germanic languages both genitives and possessive pronouns were originally postnominal. For example, in Gothic, the unmarked order is seen in swes sein lit. 'property his (in acc.)' (Luke 15: 12), though preposing for emphasis was possible as in pein swes lit. 'your property (in acc.)' (Luke 15:30). In OE, the usual position of possessive pronouns was already prenominal in prose. 
(5) $[$ Poss/Gen] [Dem] ([Adj]) [N]

a. Ne cwæð he no đin sio winestre hond, ac ðin not said he no your that left hand but your sio swiðre that right

"He did not say 'your left hand', but 'your right"'

(CP 389.20)

b. mid hire pare yfelan sceonesse \& facne with her that evil suggestion treachery 'with her evil suggestion and treachery' (BIHom 5.1)

c. he of his prem fæderlican sceate he from his that paternal bosom 'he from his paternal bosom' (BIHom 5.15)

d. Openige nu pin se fægresta fæpm \& se clæna Open now your that fairest bosom that pure 'Open now your fairest and pure bosom' (BIHom 7.24) In 5a, Jin 'your' and sio 'that' modify hond 'hand'. Our analysis, however, will treat the type 5 differently from 3 and 4 , because the possessive pronouns in 5 can be regarded as occupying a non-A position, which seems to exist in the initial position of NP in OE, as we will see in the next section. ${ }^{4}$

To sum up, we have seen that OE, ME, and EModE did not have the special functional category $\mathrm{D}$ as it was defined in section 2. In the next section, we will consider how this category arose in the history of English.

4. Topicalization in NP

4.1. ExtRACTION FROM NP. We propose a historical shift of the NP structure as follows.

(6)

a.

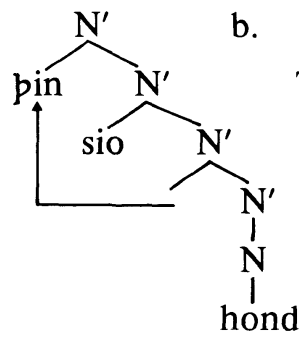

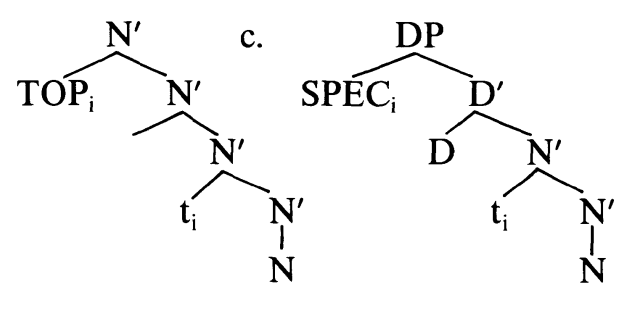

4 The pattern of 5 was lost earlier than that of 3 , probably because demonstratives and genitives/possessive pronouns joined the category $\mathrm{D}$ at different times. 
At the earliest stage of Germanic languages, genitives/possessive pronouns were generated postnominally and preposed for emphasis (cf. fn. 3 ). In the course of time, they came to be base-generated both prenominally and postnominally, ${ }^{5}$ and then they were to be adjoined to $\mathrm{N}^{\prime}$ for further prominence as in $6 \mathrm{a}$. Then this adjoined position might well be interpreted as Topic. Thus possessive pronouns and genitives are, after being assigned inherent Case by N, moved in NP for the reason of topicalization. The examples in 5 represent the intermediate stage from $6 \mathrm{a}$ to $6 \mathrm{~b}$. Further change produces $6 \mathrm{c}$, where the Topic position was reinterpreted as the Specifier position. What is noteworthy here is that in the stage represented in $6 \mathrm{a}$, the projection is never closed, while in $6 \mathrm{~b}$, Topic serves to close the projection, because a given NP will be able to have a single Topic as in a sentence. It is likely that the fixation of this position as Topic was strengthened by the concurrent loss of the inflexion especially of the feminine noun. In order to compromise the strong tendency to move the element for Topicalization and the grammatical requirement to prohibit Caseless NPs to appear, there arose the necessity to have $\mathrm{D}$ as a Case-assigner. This triggers the resetting of the value of the parameter $[\alpha \mathrm{D}]$, which is shown later.

Our proposed analysis is corroborated by the extraction of modifiers from NP observed in OE.

(7) a. hu micel sio byrðen bið ðas lareowdomes how great the burden is the-GEN teaching-GEN 'how great is the burden of teaching'

b. nu ic eower sceal frumcyn witan now I your must origin know 'now I need to know your lineage'

c. he ure wæs wealdend

he our was lord

'he was our lord'

(CP 32.6)

(Beo 251)

It was possible for the possessive pronouns and genitives in $\mathrm{OE}$ to be extracted through the escape hatch of the Topic position, since this position corresponds to $\mathrm{A}^{\prime}$ position. In 7a, Jaes lareowdomes 'of the teaching' first moves to the Topic position and then to the end of the sentence. Eower 'your' in $7 \mathrm{~b}$ and ure 'our' in 7c are also extracted from NP.

5 This kind of unspecified word order was proposed by Kato 1989. 
A similar phenomenon can be seen in Modern Greek, ${ }^{6}$ where the postnominal possessive pronouns are preposed for contrast or emphasis, and further movement may take them out of NP.

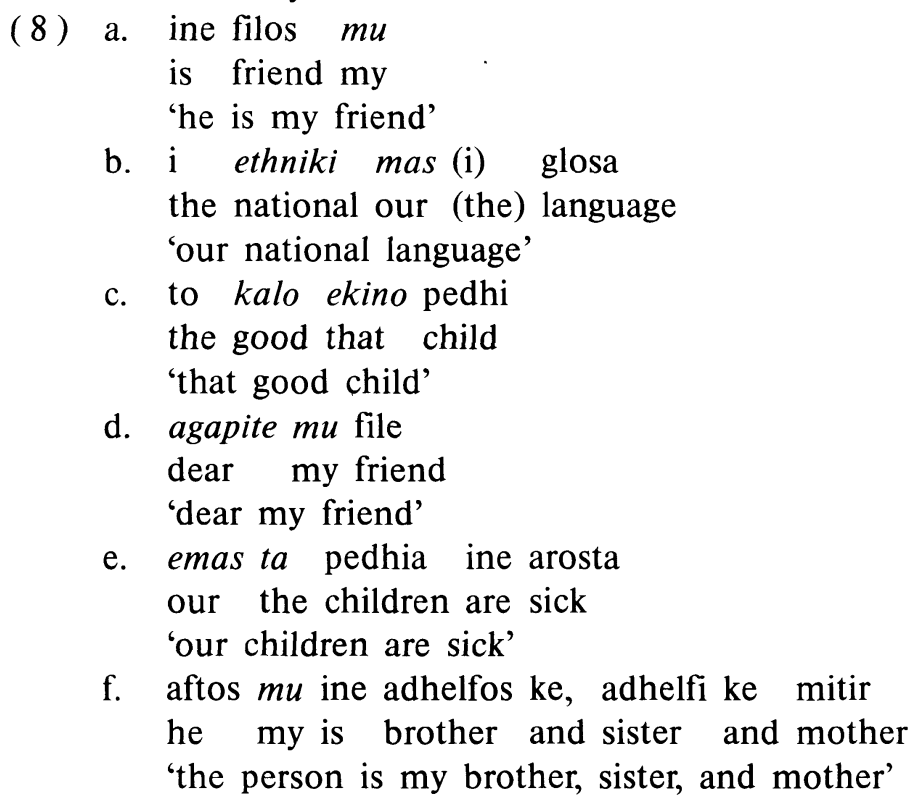

(Matthew 12: 50)

Though Greek has definite articles, indefinite articles are not fully established. Moreover, even definite articles do not close off the projection as in $8 \mathrm{e}$, nor do demonstratives or possessive pronouns as in $8 \mathrm{~b}-\mathrm{d}$. Thus possessive pronouns and genitives undergo extraction from NP as in $8 \mathrm{f}$, as pointed out by Horrocks \& Stavrou 1987.

4.2. TOPIC PROMINENCE. The suggested topicalization in NP structure in earlier English will no doubt correlate with the topic prominence

${ }^{6}$ It seems that Japanese also allows extraction from NP, with a particle $n e$ or the intonation fall on the genitive Case-marker no.

Kare-no ne, watasi e-o moratta-no
he-GEN particle I picture-ACC received-particle
'I was given his picture'

For Hungarian examples, see Szabolcsi 1983. Only the dative possessor seems to be extracted.

7 According to Horrocks \& Stavrou, demonstratives and adjectives can also be extracted in Greek, which is generally impossible in OE prose. 
in sentential structure as discussed by Vennemann 1974. Vennemann's argument that the change from TVX to SVX ( $\mathrm{T}=$ Topic) was in progress in $\mathrm{OE}$ sentences will be supported by the following examples.

(9) a. Gode ælmiehtegum si ðonc

God almighty be thank

'Thanks be to God Almighty'

b. Rihtlic pæt wæs pæt se blinda be pæm wege

right that was that the blind by the way sæte wædliende

should sit begging

'It was right that the blind man sat by the way begging'

(B1Hom 17.30)

c. \& Godes is pæt yrfe pe we big leofiap

God's is that property which we by live 'and the property by which we live is God's'

(BIHom 51.18)

d. Inpaciencia hatte an oðer senne inpaciencia is called another sin

'Another sin is named inpaciencia' (Vices \& V 13.12)

e. $p_{\text {is }}$ auh(t) elch mann te donne

this ought each man to do

'Every man ought to do this'

(Vices \& V 61.33)

f. heo Maria æfter pæs engles bletsunga \& halettunga

she Maria after the angel's blessing salutation

lange smeade

long meditated

'after the blessing and salutation of the angel, Mary meditated a long time'

(B1Hom 7.15)

g. He pa decius se casere pa he for into

he then Decius the emperor when he went into

efese mid orymme and mid prasse

Ephesus with magnificence and with pomp

'Then he, Decius the emperor, when he marched into Ephesus with magnificence and pomp'

(ÆLS 489.25)

In each sentence above the first element functions as Topic: $9 \mathrm{a}$ the dative object Gode 'God'; 9b adjective rihtlic 'right' with its complement; 9c absolute genitive Godes 'God's'; 9d complement inpaciencia, of mediopassive hatte; 9e the accusative object pis 'this'. In spite of these examples, the subject gradually became the unmarked Topic in the period of 
OE. Especially interesting are $9 \mathrm{f}, \mathrm{g}$ where the subject is apparently repeated: heo 'she' and Maria in 9f, He 'he' and decius se casere 'Decius the emperor' in $9 \mathrm{~g}$ denote identical entities respectively. The preceding pronouns correspond to Topic. This pattern seems to represent the wavering status of the sentence-initial position between Topic and subject. Such a repetition of pronouns just before subject, according to Visser (1972: 53), can be observed until the end of ME. ${ }^{8}$

If we apply the Topic-to-subject shift to NP structure, the following peculiar construction will be naturally explained. ${ }^{9}$

(10) a. Gwenayfer his love

'Gwenayfer's love'

b. Felyce hir fayrnesse

(Lawman B 22247-Mustanoja)

c. the King his son's alive

(PP1 B xii 47)

d. Madam, and if my brother had my shape And I had his, Sir Robert's his, like him

e. the king hand, the king hert

(John I i 138)

(Cursor 5410, 5903-Mustanoja)

This construction in 10a-d, so-called HIS-GENITIVE, is observed from ME to EModE, prevailing in the fifteenth century. An explanation is offered in the philological literature that his-genitive is the result of the phonological confusion of genitive ending $-s$ and his. We are not to deny this account. However, were it merely a matter of confusion, it would be completely impossible to explain the existence of a similar construction in German, whose ending cannot be confused with its possessive pronouns.

(11) dem Hans sein Buch the-DAT Hans his book

'Hans' book' (Giorgi \& Longobardi 1987. Ch. 3 n. 40) Also in 10b, the feminine hir bars the possibility of confusion, in contrast with 10a where the noun is feminine accompanied by his.

Mustanoja (1960: 160) points out that the dative of possession in OE, a special variant of ethical dative or dative of interest, is related to this construction.

(12) her

Romane Leone pæm papan his in this year Romans Leo-DAT the-DAT pope-DAT his

8 We find the type where noun precedes pronoun much later. The relation of these two patterns is not examined here. See also Visser (1963: 53-57).

9 The idea of Topicalization in NP and the relevance of his-genitive were first suggested to me by Taro Kageyama (p.c.). 
tungan forcurfon

tongue cut off

'In this year the Romans cut off the tongue of pope Leo'

(Chron an. 797-Mustanoja)

As the first element of 11 shows the dative case as in 12, Mustanoja's suggestion seems relevant. It is possible that the first noun in 10 is also dative. But even if it is the case, why did the 'dative' noun come to be fixed in this specific position? The dative noun or pronoun and the possessive pronoun were not always adjacent to each other. A typical example is given below.

(13) $\mathrm{pa}$ wæs him micel langung \& sorh on heora heortan then was them much regret sorrow in their hearts 'And they had much regret and sorrow in their hearts'

(BlHom 135.20)

Our proposed analysis provides an independent motivation to the preference of the construction: Topic position was in the process of shifting to subject position, that is, DP specifier position. Thus the possessive pronoun in 10a seems to play the role of $\mathrm{D}$ to some extent, while in $10 \mathrm{~b}$ it still remains adjectival due to the Topic Felyce. Unlike German, however, English had already lost dative ending. Therefore the first nouns of 10ac were readily reinterpreted as DP specifier. Instability is also indicated in $10 \mathrm{~d}$, where both genitive ending and a possessive pronoun are present. In 10e, king hand 'king's hand' lacks the genitive ending, which also indicates the fact that the position before noun was interpreted as Topic.

4.3. AfFECTEDNESS OF PREPOSED NPs. Anderson 1979 observes that in the NP structure of PE, only those NPs that are interpreted as AFFECTED can be preposed as in 14 .

(14) the city's destruction/the prisoner's release

$\mathrm{OE}, \mathrm{ME}$, and EModE present a striking contrast in this respect. Unaffected NPs were allowed to be preposed.

a. toeacan pæs landes sceawunge

besides the land's survey

'besides the survey of the land'

(The Voyages of Ohthere and Wulfstan) ${ }^{10}$

*the land's survey

${ }^{10}$ This example is from Sweet's Anglo-Saxon Reader, 5th ed. p.18. 
b. Godes ege on mancynne

God's fear among people

'fear of God among people'

${ }^{*}$ God's fear $(\mathrm{God}=$ Theme $)$

(ÆCHom i 22.17-Mitchell)

Cf. on pæm welme pære sopan lufan Godes \&

in the fervour the true love God's

manna

men's

'in the fervour of true love to God and men'

(B1Hom 29.10)

c. Se biscop sceal, pe wile onfon Godes

the bishop must who wants receive God's

mildheortnesse \& his synna forgifnesse

mercy his sins' forgiveness

'The bishop must, who wants to receive God's mercy and forgiveness of his sins'

(BlHom 45.7)

*his sin's forgiveness

Cf. gif hi willon Godes forgifnesse habban

if they want God's forgiveness have

'if they desire God's forgiveness' (BlHom 47.30)

d. pa men pa pe Godes rices geleafan habbað \& those men who God's kingdom's belief have healdap

hold

'the men who have and hold the belief of God's kingdom'

(BlHom 55.17)

*God's kingdom's belief

e. He aimeth not so much at the reduction of the Greeks to the truth as to his own obedience

'to the (their) obeying of himself'

(Holy War IV vi S. 177-Franz)

f. That can entame my spirits to your worship

'the worship of you'

(As III v 48)

Evidently, PE prohibits such preposing of unaffected NPs. It is generally assumed that the interpretation of affectedness obtains as the result of NP movement, for example, passivization, especially pseudo-passive (this bed has been slept in means that we see some signs on this bed that 
someone has slept here), the double object construction (he taught us linguistics implies that we have mastered linguistics), and a construction like spray the wall with paint where the wall is holistically affected. In the light of these constructions, it may therefore be justified to consider that the city and the prisoner in 14 are interpreted as affected because the effect of NP movement in sentential structure also holds for that within NP. In contrast, $w h$-movement does not yield this effect. We are thus claiming that in OE, ME and EModE the preposing within NP was whmovement, that is, Topicalization, which applied irrespective of affectedness.

Here we may touch on a similar phenomenon in Italian. Giorgi \& Longobardi (1987: Ch. 3) propose two parameters, Head-Subject and Head-Complement, instead of the Head initial/final parameter in order to capture the difference of NP structure between Romance and Germanic languages. This distinction is schematically represented as follows (Giorgi \& Longobardi 1987, Ch. 3: 5-6).
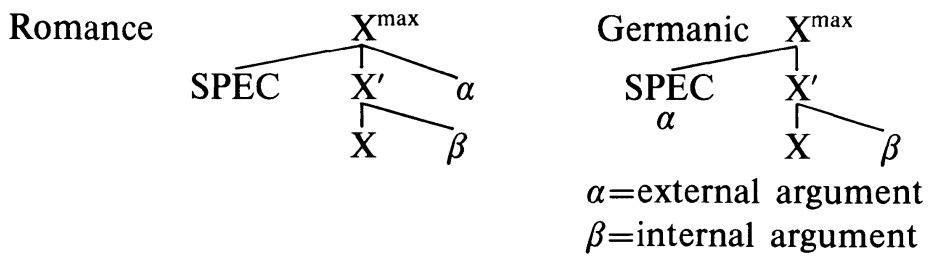

The position of the external argument is, they suppose, determined by the position of genitives and predicative adjectives.

(17) il libro di Gianni

the book of Gianni 'Gianni's book'

*il Gianni+GEN libro

(Giorgi \& Longobardi 1987, Ch. 3: 7) Italian genitives can never be prenominal as in 17 . They argue that Italian possessive pronouns can, on the other hand, appear prenominally via movement with Case assigned by agreement with $\mathrm{N}$, under the condition that Case assignment is always to the right in this language. Hence genitives have to take the form of possessive pronouns in order to be preposed. Assuming that the subject of unaffected NPs is obligatorily present, even if not lexically realized, they suggest that Italian allows preposing of unaffected NPs because the internal argument does not eliminate the external $\theta$-role by movement to Spec.

(18) la conoscenza dell' algebra 'the knowledge of algebra' 
la sua conoscenza

'its knowledge'

(Giorgi \& Longobardi 1987, Ch. 3: 33)

In English, the landing site of the movement, Spec, is the same position where the subject should originate, hence the movement is barred.

Though their parameters cannot be dismissed, we still find them insufficient when we turn to older English. As early as the OE period, the shift to complete preposing of inflected genitive was under way (cf. fn. 3). Unlike Italian, the prenominal genitives in OE were actually expelling the postnominal ones from the living language. By the end of the thirteenth century, postnominal genitives seem to have completely disappeared. $^{11}$ Since possessive pronouns were usually prenominal in OE, the shift of the base position of an external argument must have been completed at the beginning of the $\mathrm{ME}$ period. If the preposing of unaffected NPs exclusively depends on the value of the Head-Subject parameter, it will remain unexplained why the preposing continued to be active for more than three hundred years after the change of the parameter. Another question is why for a certain class of NPs the external argument is obligatory. There seems to be no ready explanation in Giorgi \& Longobardi's framework.

Our analysis, on the other hand, accounts for the preposing of unaffected NPs in Italian as follows: The landing site of the movement in NP is non-A position. ${ }^{12}$ Giorgi \& Longobardi make a different proposal in $\mathrm{Ch} .2$ where we find examples of extraction from NP.
a. la telefonata di Gianni the call of Gianni
b. la sua telefonata the his call
c. $\mathrm{Ne}$ intercetterò
la telefonata I of-him will intercept the call
d. Gianni, di cui intercetterò la telefonata Gianni, of whom I will intercept the call

(Giorgi \& Longobardi 1987, Ch. 2: 4) They argue that it is necessary for the genitives to be realized prenominally in the form of possessive pronouns in order to be extracted,

11 See Mitchell (1985: 548-49).

12 Why the Affected Constraint works on the type of fear in Italian is an open question. Giorgi \& Longobardi attribute it to the existence of a real preposition of which is not a mere Case-marker, assuming Anderson's approach. 
since genitives cannot be realized prenominally in Italian. The extraction like $19 \mathrm{c}, \mathrm{d}$ is thus restricted to the genitives moved to the escape hatch. If this observation is correct, Italian NP is not DP, but the projection of the lexical category $N$. Though the existence of the article or the demonstrative itself does not undermine this assumption, their position seems more fixed than OE or Greek.

(20) a. Il mio orologio è nuovo.

The my watch is new

b. Devi correggere questi tuoi errori.

You must correct these your errors

Italian possessive pronouns are always preceded by articles, demonstratives, indefinite pronouns or some quantifiers, and never used alone. ${ }^{13}$ Because of the fixed order, we tentatively conclude that Italian has the position of $\mathrm{D}$ without specifier, thus leaving the projection half-closed. Since the NP still has the non-A position, unaffected NP preposing is possible and the position serves as the escape hatch for extraction.

(21)

a.

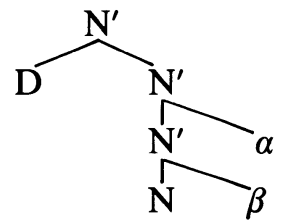

b.

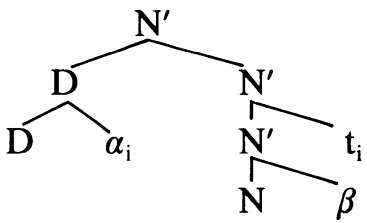

Although Romance languages require further investigation, we propose the NP structures in 21 for Italian. 21a is a structure without a prenominal possessive pronoun, and 2lb is a derived structure with a possessive $\alpha$.

5. Resetting of the parameter. Here we set up the parameter $[\alpha \mathrm{D}]$. From the observation above, we conclude that its value in English changed from $[-D]$ to $[+D]$ approximately in the fifteenth or sixteenth century. This change was triggered mainly by the necessity of having a Case-assigner for preposed NPs. Cf. §4.1. The original Topic was then reinterpreted as DP specifier, and the structure of DP was established. Our proposal will be further supported by the following historical facts.

5.1. ARTICLES. It is generally assumed that OE had no category of article. The indefinite article was not distinct from the numeral one until

${ }^{13}$ Predicative complements and family nouns are exceptions. 
the mid-thirteenth century. NPs without articles decreased rapidly through the ME period. The introduction of the category, however, did not immediately lead to the introduction of the position of $D$. But the existence of articles as a category seems to be a neccesary condition for the establishment of functional category $D$.

5.2. Modifiable Pro-Forms. As pointed out by Fukui (1986: 231), Japanese has modifiable pro-forms while PE does not.

(22) a. se-no hikui kare

*short he

b. Okinawa-de mita sore

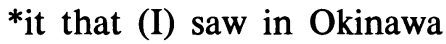

Older English does have such forms.

(23) a. supan weard hit hefdon Brittas

southern it had Britons

'Britons held the southern part' (ChronE 3.14) $)^{14}$

b. What is that was? it that is to come (Wyclif-OED)

c. pei of Troy (Brut I 6-Mustanoja)

d. I'll bring mine action on the proudest he

(Shrew III ii 234)

e. The fair, the chaste, and unexpressive she

(As III ii 10)

The modifiable pro-forms in 23 show that they are $\mathrm{N}^{\prime}$ pro-forms like those in Japanese. Through the resetting of the parameter from [-D] to [+D], these pro-forms have changed to DP or $\mathrm{D}^{\prime}$ pro-forms, and were deprived of the possibility of further modification. ${ }^{15}$

5.3. Group GENITIVE. In PE, group genitive is totally acceptable. Its history will be described as follows.

(24) a. Ælfredes cyninges godsunu

Alfred's king's godson

14 This example was brought to my attention by Kageyama (p.c.)

15 In many of the OE examples, modifiers are hard to distinguish from predicative adjectives. For example:

ierre he hwearf ponan to his agnum angry he returned thereupon to his own

In modern intuition, the role of ierre should correspond to participial construction with no dependency on he itself. 
'the godson of king Alfred'

(ChronA an. 890)

b. on Herodes dagum cyninges

in Herod's days king's

'in the days of king Herod'

(ÆCHom i 194.21-Mitchell)

c. the kyng Priamus sone of Troye

d. the grete god of Loves name

(HF 1489)

It is generally believed that $24 \mathrm{a}, \mathrm{b}$ are the beginning of the group genitive. In 24a, both Alfredes 'Alfred's' and cyninges 'king's' appear prenominally, whereas the split pattern of $24 \mathrm{~b}$ seems to be more usual. Again we observe that the first genitive in $24 \mathrm{~b}$, c is interpreted as Topic. After $24 \mathrm{c}$ took over the old inflected type, there was a slight time gap between $24 \mathrm{c}$ and $24 \mathrm{~d}$. The true group genitive like $24 \mathrm{~d}$ became common in the fifteenth century. What enabled phrasal level to appear prenominally is the establishment of $\mathrm{D}$ for a Case-assigner $-s$ and the position of the specifier as a result of the proposed parametric shift. ${ }^{16}$

6. Conclusion. We have proposed that postulating a parametric shift from [-D] to [+D] explains a variety of facts in the history of English, most of which were previously taken as idiosyncratic and unrelated to one another. We have argued that the loss of double determination, extraction from NP, unaffected NP preposing, modifiable proforms, and his-genitive, together with the development of the article, and group genitive, all fall out from the shift of the single parameter.

\section{REFERENCES}

Abney, Steven. 1987. The English noun phrase in its sentential aspect. MIT dissertation.

Allen, Cynthia. 1975. Case marking and the NP cycle in Old English. LA 1.389403.

Anderson, Mona. 1979. Noun phrase structure. University of Connecticut dissertation.

16 An anonymous reviewer suggested the relevance of the fact that a genitive or a possessive pronoun was able to be an antecedent of a relative pronoun. Since this type was observed until EModE, it might be related to the facts mentioned in this section. 
Franz, Wilhelm. 1939. Die Sprache Shakespeares. Halle: Max Niemeyer.

FUKUI, NAOKI. 1986. A theory of category projection and its applications. MIT dissertation.

- 1988. Deriving the differences between English and Japanese: A case study in parametric syntax. English Linguistics 5.249-70.

Giorgi, Alessandra, and Giuseppe Longobardi. 1987. The syntax of noun phrases: Configuration, parameters and empty categories. ms.

Horrocks, Geoffrey, and Melita Stavrou. 1987. Bounding theory and Greek syntax: Evidence for wh-movement in NP. Journal of Linguistics 23.79-108.

Kato, Kozo. 1989. Koeigogojun-no fujiyuusei. Jinbunkagaku Ronsyu 23.149-58.

Lightfoot, David. 1979. Principles of diachronic syntax. Cambridge: Cambridge University Press.

Mitchell, Bruce. 1985. Old English syntax. 2 vols. Oxford: Clarendon Press.

Mustanoja, Tauno. 1960. A Middle English syntax. Helsinki: Société Néophilologique.

Szabolcsi, AnNa. 1983. The possessor that ran away from home. The Linguistic Review 3.89-102.

Vennemann, Theo. 1974. Topics, subjects, and word order: From SXV to SVX via TVX. Historical Linguistics I, ed. by John Anderson and Charles Jones, 33976. Amsterdam: North-Holland.

VISSER, F. Th. 1963. An historical syntax of the English language, part I. Leiden: E. J. Brill. 